
SANITATION AND HOUSING QUALITY IN URBAN WORKERS' HOUSING IN THE ANCOATS AREA OF MANCHESTER BETWEEN 1800 AND 1950

\author{
MICHAEL NEVELL
}

This paper will look at some of the excavated material for British urban workers' housing, built and occupied during the period 1800 to 1950 in the Ancoats area of Manchester: Ancoats was notorious amongst contemporary writers and campaigners for its poor quality and over-crowded housing. This archaeological evidence has emerged as a result of developer-funded excavations and represents part of a growing body of data collected since 1990 from within many of the great industrial cities of Britain (Glasgow, London, and Manchester), as well as excavations in the numerous smaller industrial manufacturing towns of the UK. In this study particular attention is given to the impact of national legislation, private acts and local bye-laws aimed at improving industrialized living conditions and the build quality of $19^{\text {th }}$ century workers' housing occupied into the $20^{\text {th }}$ century. Using excavated examples from more than 50 houses within Ancoats it will be argued that archaeology can provide a distinctive and unique view of urban domestic life in the $19^{\text {th }}$ and first half of the $20^{\text {th }}$ century, whilst demonstrating continuity in occupation patterns during this period. The evidence for urbanized, industrial, living also compliments the more extensive archaeological studies of manufacturing industry from the period.

Key words: back-to-back, court housing, drainage, sanitation

\title{
INTRODUCTION
}

The long economic boom of the period 1992-2008 saw in Britain a focus on the redevelopment of city centre locations, 'brownfield sites', and a resultant upsurge in the investigation of industrial period remains. At the same time the impact of the introduction in England and Wales of Planning Policy Guidance Number 16 in 1990 brought about a period of developer-funded archaeological work that encouraged a greater focus upon the whole story of an archaeological site, including $19^{\text {th }}$ and $20^{\text {th }}$ century material. One consequence was the investigation of large numbers of urban workers' housing either through standing building surveys or through excavations. Notable areas of activity have included Birmingham, Glasgow, London, Sheffield, and York. ${ }^{1}$ Industrial housing (workshop dwellings, blindbacks, back-to-backs, court houses and through-houses) was a necessary counterpart to the urban, steam-powered, factory. Factory owners' needed to be able to guarantee a regular supply of labour, in return for standardised wages and hours. A new landless tenantry, accommodated in purpose-built urban houses, emerged to fulfil this need in the industrializing cities of $18^{\text {th }}$ and $19^{\text {th }}$ century Britain, with Manchester the leading example. ${ }^{2}$ Demolition due to housing improvements from the late $19^{\text {th }}$ century onwards and later waves of rebuilding activity means that archaeology is now the only way of revealing the range and quality of this housing in many of these industrial cities.

Detailed publication and synthetic studies of the British evidence remains unusual. Nevertheless, recent work has suggested a number of avenues of research using this data: housing quality, health and poverty; material culture and social networks; the rise of consumer production; and landholding and tenancy being just a few examples. ${ }^{3}$ 
This paper will seek to explore the archaeological evidence for the issues of sanitation, housing quality and later re-use during the years 1800 to 1950, drawing upon excavations and building surveys from the Ancoats district of Manchester (Figs 1 \& 2). Ancoats was notorious amongst contemporary writers and campaigners for its poor quality and overcrowded housing. However, Belford has drawn attention to one of the dangers in looking at these subjects, namely assuming that $19^{\text {th }}$ and early 20th-century views of what constituted a 'slum' area were accurate and free from bias. ${ }^{4}$ A further problem is making sure than a distinctive archaeological approach is taken that uses the primary source material (the physical evidence) rather than seeking to answer questions better suited to social or historical approaches. Thus, this study will look specifically for evidence of the implementation of national legislation, private acts and local bye-laws for housing improvement through the physical evidence of housing occupied in the late $19^{\text {th }}$ century and the early $20^{\text {th }}$ century, rather than studying the new-build properties in Ancoats from the 1890 s and early $20^{\text {th }}$ century. The differences in the provision of utilities between the $19^{\text {th }}$ century and the early $20^{\text {th }}$ century presented here sheds light on the accuracy of contemporary perceptions of the dwellings. ${ }^{5}$

\section{THE LEGISLATIVE FRAMEWORK}

Manchester's housing was not built within a vacuum, but reflected the evolving local land holding and renting patterns, and the spread of unregulated house building within the new British industrial cities and towns of the $19^{\text {th }}$ century. Many of these urban areas saw a trebling or quadrupling of their population in the first half of the century. Manchester's population, for instance, (based upon the municipal boundaries of the 1838 town; Fig 3) rose from 76,778 in 1801 to 316,213 , in 1851 . Although the boundaries of the industrial town were increased in 1838 to encompass the newly urbanising areas of Ardwick, Beswick, Cheetham, Chorlton-upon-Medlock and Hulme the population density per acre of the pre1838 township more than doubled in this period, using the measurements of the period from 42.77 people per acre in 1801 , rising to 86.29 people per acre in 1831 , and 113 in 1851 . As late as 1904 Manchester had 42 people per acre. ${ }^{6}$ Strangely, the number of people per house in the old township fell slightly in the early $19^{\text {th }}$ century, from 6.96 people per house in 1801 to 6.33 people per house in $1831 .^{7}$ Archaeology can now demonstrate that this apparent conundrum can be explained by the construction of increasingly smaller properties as more and more people were packed into smaller and smaller spaces: humans had become more of a commodity than houses. ${ }^{8}$

The construction boom of the early to mid- $19^{\text {th }}$ century eventually led to a response in local and national government. Nationally, this took the form of the Labouring Classes Dwelling Houses Act of 1866 and the Artisans' and Labourers' Dwelling Act of 1868. The latter Act enabled companies or municipalities to borrow more cheaply to build new labourers' dwellings by clearing slums. It also established two important principles. ${ }^{9}$ Firstly, that the state had the will and power to interfere with the rights of property owners to improve public health. Secondly, that it was the duty of the landlord to keep a property in good repair.

The Local Government Act of 1871 and the Public Health Act of 1872 created a network of rural and urban sanitary authorities within England and Wales which in theory could deal more effectively with the housing problem. The Public Health Act of 1875 made compulsory the appointment of a Medical Officer of Health in every sanitary district of England and Wales. A sanitary district was governed by an elected sanitary authority and was responsible for various public health matters such as providing clean drinking water, sewers, street cleaning, and, most importantly for the current discussion, clearing slum housing. This act

\section{Comment [MW3]: I can't correct the formatting here, which is odd.}

Comment [MW4]: Should these should
be per hectare?
Comment [MP5]: You could get round
this by a statement about using old
measurements when dealing with archive
material? After I, those were the
measurements then being used!

Comment [MP6]: This would be an unfamiliar concept to most of our readers a short explanation needed? 
also consolidated the earlier legislation and dealt with food adulteration, sewers, drainage and epidemics. Later legislation that dealt with housing quality and health included the Housing of the Working Class Act passed in 1890, the Public Health Acts of 1907 and 1936, the Housing \& Planning Act of 1909 which banned the building of back-to-back houses, another Housing Act of 1930 which allowed for the demolition of slum areas, and the New Towns Act of 1946 which marked a decisive shift towards mass-housing building on greenfield sites. $^{10}$

Private Acts and local bye-laws also addressed housing problems in individual towns. In Manchester the Police Commissioners (established in 1792 when Ancoats became Police District No.1) and then the new Borough Council (established in 1838) were responsible for taking action to improve the draining and paving of streets.. Thus, after 1792 the Commissioners introduced a series of bye-laws controlling street widening and improvement as well as building regulations that specified the requirement for and condition of party walls, joists, load bearing timbers and chimneys. A Nuisance Committee was setup in 1800 to deal with the dangers posed by projecting cellar steps and unfenced cellar holes, whilst in 1801 a party-wall surveyor was appointed. By 1811 the Commissioners were repairing soughs and drains from police funds and in 1830 a minimum street width of 24 feet $(7.32 \mathrm{~m})$ was decreed. ${ }^{11}$ The Police Commissioners came to act as the de facto council for the rapidly expanding industrial town, recognising that bad sanitation and poor building quality were threats to health and public order. A few years after its establishment the new Borough sponsored the Manchester Police Act of 1844, which apart from establishing judicial courts in the industrial town had clauses allowing the new local authority to insist on the provision of privies for new houses and to ban the building of back-to-back properties. In 1853 a new local bye-law allowed the Borough to prevent the building and habitation of cellars, thus rendering illegal a complete class of dwelling. The privately sponsored Manchester Waterworks and Improvement Act of 1867 was aimed at removing back-to-back houses in the city. Thus, it required landlords to renovate, recondition or change the use of existing back-to-backs. This was a very significant moment since, until 1867, all of these regulations applied to new-build properties, not the earlier housing stock, with the exception of the banning of cellar dwellings. ${ }^{2}$ The archaeological evidence for whether this was enforced is dicussed below. No further municipal action was taken until the formation of the Unhealthy Dwellings Committee in 1885. This body had instructions to enquire into insanitary dwellings and led to the Manchester Labourers' Dwellings Scheme which was approved by the City in 1890. Under this scheme the northern part of Ancoats bounded by Cornwall Street, George Leigh Street, Bengal Street and Oldham Road was declared an 'Unhealthy Area' the 'evils and defects' of which 'could only be remedied by the rearrangement and reconstruction of the streets and houses'. ${ }^{13}$ Other areas in Ancoats were also declared unhealthy and one consequence was the construction by Manchester City Council of the model tenement block Victoria Square in 1894. At the same time the city built cottages on George Leigh Street and Sanitary Street (now Anita Street). ${ }^{14}$

There was then a pause in the provision of new bye-laws and acts affecting Ancoats until the 1930 Housing Act, which required all local councils to clear any remaining slum housing and gave grants to re-house those living in them. ${ }^{15}$ After the Second World War the Housing Repairs and Rents Act of 1954 required all local authorities to survey their housing needs at the same time that fresh national criteria were established to define houses that were unfit. ${ }^{16}$ The consequence of these two national acts was that Ancoats ceased to be a residential suburb. 
The following discussion looks at the archaeological evidence for sanitation within the northern half of the Ancoats area, between 1800 and 1950. The study area is bounded to the west by Great Ancoats Streets, to the north by Oldham Road, to the east by Prussia Street and to the south by the Rochdale Canal (Fig 1). The archaeological evidence is examined in order to record the pattern of the development of sanitation and only then studied to see if there is any correlation with the historical evidence. That way the unique data provided by archaeological building survey and excavation work is kept central to the current investigation.

\section{INDUSTRIALISATION AND ANCOATS}

Until the 1770s Ancoats was a rural area on the eastern side of the town of Manchester. In the last quarter of the 18th century the population of Manchester trebled from around 20,000 in 1773 to 76,778 in 1801 . This trebling of the population was helped by the shift of the town's textile industry from hand-based spinning and weaving (which was focussed in the North Quarter adjacent to Ancoats) to steam-powered factory cotton spinning. ${ }^{17}$ Ancoats played a central part in this growth as the town's first industrial suburb, with land within this area being given over to the construction of weavers' cottages, steam-powered cotton factories and workers' cottages. The starting point for the urban development of Ancoats is said to have been in 1775 when part of the Great Croft between Ancoats Lane and Newton Lane (the present Great Ancoats Street and Oldham Road) was sold to Thomas Boond (also known as Bond), a bricklayer, by George and Henry Cornwall Legh, members of the Cheshire gentry. ${ }^{18}$ By the time of Green's map of Manchester, published in 1794 a grid-iron of streets had been laid out between Great Ancoats Street and Oldham Road. Property not only lined those main thoroughfares but had also begun to be built in the streets behind. At this date development was densest in the northern part of Ancoats, Police District No. 1, in area which lay closest to Great Ancoats Street and Oldham Road and included roads named after some the early land owners and builders: Boond, Cornwall, George Leigh, Henry and Maria. Elsewhere, building was more scattered, with many blocks of the grid-iron still vacant. Amongst the first back-toback houses to be built in Ancoats were a set of ten properties built on land on Portugal Street bought by Thomas Overton in 1790, from Christopher Wilde and James Woodroffe, who in turn had bought the land from Henry Cornwall Legh. By 1801 there were 11,039 people, a seventh of Manchester's population, living in the new industrial suburb.

During the early 19th century the industrialisation of Ancoats continued unabated (Fig 4), with glass works and engineering companies joining the textile mills, and this process attracted workers from both the rural hinterland of Lancashire and also from areas further afield, notably Ireland. Rate books indicate that one of the earliest set of court housing in Ancoats, that is infill dwellings built on the backyards between properties, was Nedin's Court which lay between Silk Street, George Leigh Street and Poland Street and was built around 1814. By 1851 most of the land in Ancoats had been built upon and in that year its population numbered 55,983. ${ }^{19}$ Adshead's map of the Ancoats' area, published as part of a city-wide survey in 1851, shows 1532 terraced houses, cellar dwellings, back-to-back houses and court housing in amongst the mills of the northern Ancoats area (Fig 5). A survey by the Manchester Board of health in 1831, at the time of the cholera epidemic, recorded that 55.4\% of Ancoats' houses were without plumbing, and that $56.1 \%$ of all streets in the area were not cleaned, becoming dumping grounds for heaps of refuse and human waste. ${ }^{20}$

For contemporary observers Ancoats' urbanisation was dramatic even by Manchester's standards, as were the consequences in terms of living conditions. In the early 1840s Frederick Engels visited Ancoats as part of his investigation into the conditions of the

Comment [MW11]: Leigh? I've seen both spellings but you use Leigh below. Also, should it be Cornwall-Leigh?

Comment [MW12]: see above 
working classes in Britain. During this visit he considered the construction of the workers' houses in the area around Jersey Street and commented that '...on closer examination, it becomes evident that the walls of these cottages are as thin as it is possible to make them. The outer walls, those of the cellar, which bear the weight of the ground-floor and roof, are one whole brick thick at most..., ${ }^{21}$

This period of rapid population growth and increased pressure on housing quality was followed in the later 19th century by a slow improvement in housing quality through local by-laws that led to the addition of backyard privies, the closure of cellar dwellings and the demolition or conversion of back-to-back houses. ${ }^{22}$ Improvements in the living conditions of the industrial suburb, however, could be slow. In 1889 Dr John Thresh presented a paper to the Manchester and Salford Sanitary Association, in which he examined the reasons for the continued high mortality in No. 1 District in Ancoats. This was a 36 acre area between Great Ancoats Street, Oldham Road, Union Street and German Street.l Thresh reported that the majority of houses in this district (over 800) had been built before 1830, some even before 1780; about 60 had been built between 1830 and 1850, but none after that last date. Most were two-storey, but there were also several three-storey houses, with a workshop in the garret. Back-to-backs accounted for about a third of the dwellings in the district. Many houses had cellars described as being used as workshops or for storage. ${ }^{23}$ In 1904 T R Marr reported the results of his own inspection of District No. 1 (northern Ancoats; Fig 6). He introduced the area as follows: 'It contains nearly 600 dwellings, varying in size from six to two rooms. Houses of the latter type are back-to-back and are gradually tending to disappear under pressure from the Sanitary Committee of the Corporation. The streets are narrow with few exceptions and there are several cul-de-sacs and courts' ${ }^{24}$ Marr noted that the population density of northern Ancoats, District 1, was more than four times the Manchester average of the period, at 203 people per acre compared to 42 people per acre across the whole city. Even so, he observed that 'overcrowding in the individual houses is apparently not very common. It has to be remembered that this is now an offence if persisted in, and in any case may lead to inconvenience if the sanitary authorities take action, and that consequently some pains are taken to prevent the discovery of its existence'. Almost half the dwellings he studied were four-roomed (i.e. two-up two-down), whilst a third were still two-roomed. ${ }^{25}$

For the majority of houses still standing in Ancoats in the 1930s, their subsequent fate was not conversion or replacement but demolition as recorded in the newspapers and council minutes of the city from the mid- $20^{\text {th }}$ century. This took place after the Second World War, when the remaining late 18th and 19th century houses in Ancoats were demolished as slums, and their sites often left vacant

\section{THE LIFE CYCLE OF THE HALL'S COURT HOUSING}

Whilst the outlines of the spread and demolition of workers' housing within Ancoats is well known individual case studies have been few; the work of the Manchester Early Dwellings Research Group in the 1980s being a notable exception. This pioneering research included studies of surviving early $19^{\text {th }}$ century properties on Silk Street/Poland Street, since demolished. ${ }^{26}$ Excavation thus offers the best avenue for providing fresh physical data on the case histories of individual properties within Ancoats. Between 2005 and 2007 several sites were investigated on Bradley Street, Holditchs Court and Shilling Court off Jersey Street, and either side of Loom Street between Sheratt Street and Bengal Street. ${ }^{27}$

One detailed example, investigated within the study in 2011 by the University of Salford, was a set of 10 back-to-back houses and a through-house at the corner of Jersey Street and

Comment [MP15]: By you? Is this part of the study area? 
Pickford Street forming Hall's Court (Figs 7 \& 8). These were built between 1794 and 1800 , making them amongst the first court housing in Ancoats. The early date of this housing and their late demise - the buildings were finally demolished in 1970 - make this a very important grouping within Ancoats, as this court housing spans almost the full history of the industrial suburb. ${ }^{28}$

The first detailed map to show the excavation area was Green's map of Manchester, published in 1794 (Fig 4). Both Jersey Street and Pickford Street, the latter then denoted as 'Gun Street', had been laid out by this date although the site of halls court was vacant. By Roper's map of 1807 the houses forming Hall's Court had been built. The houses are shown in detail on Banck's map of Manchester from 1830 (Fig 4). A passageway ran from the eastern side of Jersey Street giving access to the southern row of five back-to-backs. The other side of the passageway was occupied by a school. Hall's Court comprised a block of ten, two-storey, back-to-back properties forming numbers 1 to 7 Hall's Court to the south, Nos. 4 and 6 Jersey Street to the west, and Nos 2 to 8 Pickford Street to the north (Fig 9). At the eastern end of these back-to-backs was a larger two storey, 'L' shaped, structure, the through-house, which fronted Pickford Street and abutted No. 93 Great Ancoats Street (the Kings Arms) to its rear (Fig 4). Documentary and cartographic sources from the mid-19th century confirmed Nos. 4 and 6 Jersey Street functioned as commercial premises but had living accommodation on the upper floors. In contrast numbers 1 to 7 Hall's Court and 2 to 10 Pickford Street were all private dwellings and census returns from the period have established that these properties were occupied by local mill workers and trades people.

During the late 19th century the buildings at Hall's Court were substantially redeveloped and these changes are depicted on Goad's insurance map, copies of which survive from the beginning and end of $1888 .{ }^{29}$ Goad's earlier map, dated February 1888, shows that the study area had not changed since Adshead's map of 1851. However, the internal walls of the backto-back houses on Pickford Street were marked as being 'imperfect' indicating that the properties were in need of repair at this time. Goad's later map of 1888 captures the moment when these houses were converted, the set of housing associated with Hall's Court appearing to have been redeveloped with changes being made to the internal footprint of most of the buildings. This was almost certainly part of the continuing policy of the council to convert or remove back-to-back houses in Manchester and demonstrates Dr John Thresh's observation about the length of time it was taking to get rid of the worst kind of housing (see above).

Goad's later map of 1888 shows that numbers 4 and 6 Jersey Street were extended by knocking through into Nos. 1 and 3 Hall's Court and No. 2 Pickford Street to create two larger commercial premises which functioned as a hairdressers and general provisions store. The most substantial alterations made to the houses appear to focus on the back-to-back housing located at Hall's Court and Pickford Street. Number 5 Hall's Court appeared to have been demolished and replaced by a single storey out building and yard. Number 7 Hall's Court also appears to have been demolished and in its place was the single storey, rear, extension of number 8 Pickford Street. Census returns from the period confirm that by 1891 Hall's Court ceased to be used as dwellings and the area was referenced as being uninhabited. Similarly, number 2 Pickford Street was knocked through to serve as an extension to Number 6 Jersey Street. Number 4 Pickford Street was demolished and replaced by a single storey structure with a front yard possibly serving as an out building for number 6 Jersey Street, whilst numbers 6 and 8 Pickford Street were knocked through to create one larger dwelling, with a single storey extension to the rear of number 8 , which occupied the land where number 7 Hall's Court had formerly stood (Fig 9). The internal layout of number 10 Pickford Street 
appeared to remain unaltered although Goad's later map from 1888 does show that a third floor had been added to the northern half of the building which fronted Pickford Street.

During the mid-20th century there was little change in the layout of the study area, with the majority of the buildings continuing to function as they did during the early part of the century. The only exception to the above was the demolition of numbers 6 to 10 Pickford Street which were replaced by a single storey industrial unit by the 1960 s. Trade directories from this period revealed little information about the purpose of this unit, although photographs have revealed that it functioned as a takeaway food outlet prior to its demolition in the early 21 st century. The rest of the former properties were demolished in 1970.

\section{THE HALL'S COURT EXCAVATION EVIDENCE}

Four phases of activity were identified by the excavations of the housing at Hall's Court; the construction of the dwellings, the first episode of alterations, major refurbishments and the final demolition of the properties (Fig 10). ${ }^{30}$

The initial construction phase was represented at the western end of the site by the fragments of external walls (001), (002) and (004) and internal dividing walls (005) and (006) (Figs 10 $\&$ 11). All were constructed using the same bonding style and similar handmade bricks measuring $9 \times 41 / 4 \times 3$ inches which were widely used elsewhere in Ancoats during the 19th century. Although fragmentary, these walls closely matched the historic mapping of the area and confirmed the original footprint of the back to back housing. This primary phase saw the building of 10 back-to-back properties all sharing a central party-wall of a single brick thickness. The foundations for the outer walls were two to three bricks deep, whilst the partywall appeared to rest on the truncated subsoil. Each house had a footprint that was roughly; $3.5 \mathrm{~m}$ by $4.5 \mathrm{~m}$ in plan. Only the properties fronting Jersey Street appeared to have been heated by a fireplace, whilst there was no indication of any staircases. The latter might be due to some truncation by late 20th-century activity across the eastern part of the site, although the archaeology covering the western half of the court housing, which included the properties fronting Jersey Street, was far better preserved and yet there was still no evidence for a staircase. Underlying the secondary clay flooring (024), see below, at this end of the site was a brick drain (030; Fig 12), containing Buckley Ware pottery, which appears to have acted as a primary soak-away.

Very little evidence survives of the original walls of the housing in the eastern half of the site due to the disturbance of this part of the site by the building of a late 20th century industrial unit which had roughly the same footprint as numbers 6 and 8 Pickford Street combined. The only walls identified as belonging to this phase were (065), the eastern external wall of number 10 Pickford Street, (052) the dividing wall between the back to back housing and 10 Pickford Street and (040) the possible remains of one of the demolished dividing walls identified as 'imperfect' on Goad's earlier map. All three walls were severely truncated, particularly to the east, by the 20th century foundations and to the south of (052) by the concrete drainage system and manhole.

The second phase of activity (Fig 10) encompassed changes that were made to the properties in the mid-19th century. On the western side of the site, the interior of two houses facing Jersey Street was altered by the addition of an internal partition (008) suggestive of a rear corridor. This may be associated with the change of usage of these two properties from domestic to commercial activity. These alterations also seem to have involved the raising of the ground floor level by c. $0.25 \mathrm{~m}$. This can be seen by the presence of walls (012)-(015) which seem to have functioned as piers to support the higher floor surface. The clay layer 
(024; Fig 13) also seems to have been related to this activity as a filling deposit in the cavity between the original and secondary floor surfaces. The lack of visible cuts for walls in this layer and the presence of features (drain (030)) below it would indicate that it was indeed a later deposit.

The floor level covering the eastern half of the site was also raised using the clay layer (024), whilst two sets of brick built piers; (037) and (038), (042) and (059) represented the insertion of more raised flooring from this phase. In addition to these floor supports several other small walls were identified on the western side of the site and may have represented minor ephemeral internal structures, perhaps staricases, which were later removed as part of the major refurbishments in phase 3 .

The other structures recorded as part of this second phase were all related to the larger building at 10 Pickford Street. Towards the north-eastern edge of the excavation area were two walls; (066) and (067). These walls do not appear on Adshead's or Goad's later maps but can be seen on the earlier of Goad's maps, suggesting that they may have been added around the time that the building became a carpenters' workshop or gained its extra storey in the mid-19th century. (Nash, 2011) Layer (074) lying against (066) may have served as a rough exterior surface associated with the yard also seen on this 1888 map. To the south lay the possible remains of an exterior paved surface and external walls of a storage building identified at the rear of 10 Pickford Street represented by (062), (061) and (063) respectively. Like walls (066) and (067) these features only appear on the earlier of Goads maps and seem to have been removed during the major refurbishment works of the later 19th century.

The third phase of activity (Fig 10) within the court housing was represented by the construction of structures on top of the clay layer (024) associated with the major refurbishments from the late $19^{\text {th }}$ century and probably to be identified with the later Goad map from the end of 1888. The first of these was a small section of wall (025), between pillars (009) and (010). This appeared to be the later brick filling of a void, possibly a fireplace, in wall (006) constructed on top of the contemporary floor level. A second structure relating to this phase was identified in the centre of the site as a collection of brick surfaces represented by contexts (020)-(022). Together these features formed a floor surface and the close proximity of drains and lead water pipe would suggest that this may have been a kitchen or washing area, possibly part of the single storey outbuilding that replaced number 4 Pickford Street.

At the eastern end of the site Nos. 3 and 4 Hall's Court were demolished and replaced by single-storey outbuildings. Associated with this transition a number of brick surfaces identified lying on top of the clay layer similar in form and nature to (020)-(022). This included a section of lead pipe protruding from the compacted surface (057) between (056) and (058), indicating that these properties, if not all of the court housing, had been provided with running water during this phase. The final features relating to this phase were the three walls (053)-(055) to the south of (052) which may be associated with further alteration work on 10 Pickford Street and the store to its rear. The cartographic evidence shows that the corner of this storehouse was rebuilt following the demolition of number 8 Pickford Street as the two buildings shared walls.

The final phase of activity (Fig 10) covers the demolition of the workers housing and the construction of a late $20^{\text {th }}$ century car park and associated barrier posts at the western end of the site, and the construction of a late $20^{\text {th }}$ century industrial unit. This latter structure appeared in cartographic and photographic evidence from the 1970s, during which time it
Comment [MW22]: why square brackets here? 
may also have undergone minor alterations. The most extensive remains of this building were the external machine made brick cavity walls which were identified around all four edges of the excavation area. This structure was demolished shortly before the excavations in 2011 .

There are several striking features from this detailed case study. Firstly, the excavations failed to find any evidence for toilet facilities, neither earth closets nor flushing lavatories, Secondly, evidence for drainage in the early to mid- $19^{\text {th }}$ century took the form of a single drain soak-away: running water is not evidenced until the end of the $19^{\text {th }}$ century, around 1888. Thirdly, there was no evidence for a gas supply into any of the properties. Finally, the evidence for material culture, (pottery, glass, metalwork), was confined to two periods of activity; the primary construction phase from the period 1794-1800, and the demolition phase from the late $20^{\text {th }}$ century.

\section{LOOM STREET HOUSING EXCAVATIONS}

The evidence from one set of court housing might be seen as exceptional, in terms of their build quality and the lack of evidence for sanitation throughout their life-cycle. However, the more extensive excavations within the northern Ancoats study area, was at Loom Street, in the autumn of 2007 by the University of Manchester (Fig 14). Seven area excavations in a block of land either side of Loom Street bounded by George Leigh, Bengal, Sherratt and Blossom Streets (Areas A to G; Fig 15) exposed the complete or partial floor plan of 46 dwellings, provides a supporting story of haphazard implementation of sanitary and building regulations. ${ }^{31}$

The Loom Street excavations represent one of the largest archaeological investigations of late $18^{\text {th }}-, 19^{\text {th }}$ - and early $20^{\text {th }}$-century workers' housing within the city. ${ }^{32}$ The map sources indicate that the Loom Street study area (Fig 16) began developing during the late $18^{\text {th }}$ century through the construction of double-depth and through properties. The impetus appears to have been the early industrialisation of the neighbouring streets, which included the establishment of numerous textile mills concentrated along Union Street. ${ }^{33}$ In many respects, the excavations at Loom Street represent a microcosm of the early to mid- $19^{\text {th }}$ century industrial development within Ancoats and Manchester. Housing types built during this period in the Loom Street area included back-to-backs, blind-back houses, court housing and double-depth houses. This period also saw a more intensive occupation of the older housing stock within the study area and the creation of cellar dwellings.

In terms of housing quality the best constructed were the largest and oldest properties fronting George Leigh Street, which were built before 1794 probably as workshop dwellings. ${ }^{34}$ These were exposed during the excavation of Area A and Area D (Fig 15). These properties measured c.5.5m wide (Houses D2-3) close to the corner of George Leigh Street and Bengal Street, narrowing to $c .4 .7 \mathrm{~m}$ wide further along George Leigh Street (House D3 \& A1; Fig 17). Each of the properties was provided with half-basements and raised ground floors. One of the excavated basements (House D1) contained a fireplace. An unexcavated late $18^{\text {th }}$ century house fronting Bengal Street was associated with a square brick built outshut, a single-roomed, single-storey structure with a mono-pitched roof, the remains of which were exposed in Area D. Though the function of this outshut was not entirely clear, it is possible that it was subdivided into individual earth-closet privies, which were shared by the inhabitants of the double-depth houses. The recovery of architectural pieces form a porticoed doorway from one of the houses, together with their comparatively large internal areas, indicated that these properties were originally constructed as higher status dwellings. Indeed, it is possible that during this period these dwellings housed artisans, as was the case

Comment [MW23]: Do you need to
define this term?
$\begin{aligned} & \text { Comment [MP24]: I think it is a frilly } \\ & \text { well accepted term? }\end{aligned}$


with a larger late $18^{\text {th }}$ century property found on nearby Sherratt Street, which contemporary rate books and trade directories indicate was occupied by a shoemaker during the early $19^{\text {th }}$ century. ${ }^{35}$

The properties (Houses B1-2, B4-5; Fig 18) excavated close to the corner of Loom and Sherratt Street were slightly smaller in size, measuring $4.5 \mathrm{~m}$ wide by $7 \mathrm{~m}$ deep, though were probably of a similar status to those flanking George Leigh Street. These properties differed in one major respect in that they did not have basements. Instead, the remains of two of these houses (Houses B4 \& B5) indicate that each property was composed, at ground level, of two $3.5 \mathrm{~m}$ deep rooms. In the rear rooms of houses B4 and B5, which would have been positioned behind the parlour, the remains of fireplaces attached to the eastern partition walls were identified. An outshut was also exposed, linked to the rear of house B4, which may have functioned as a shared earth-closet privy.

The double-depth houses (Houses E1-3; Fig 21) excavated on the southern side of Loom Street, towards its eastern end, were also built by 1794 but were smaller in size and were presumably of lower status than the late $18^{\text {th }}$ century houses fronting George Leigh Street. These properties did not have basements. The remains indicate that each house measured $4 \mathrm{~m}$ wide by $6.5 \mathrm{~m}$ deep, and was composed of a $c .2 .8 \mathrm{~m}$ deep rear room and a larger $3.7 \mathrm{~m}$ deep front room. Within the rear room of the properties were fireplaces and flights of stairs allowing access to the first floor.

Later double-depth houses were built between 1836 and 1843 on the southern side of Loom Street adjacent to No. 1, No. 2 and No. 3 Courts (see below; Houses G5-7). Houses G1 to G4 (Fig 22) were each $c .3 .8 \mathrm{~m}$ wide by $6.2 \mathrm{~m}$ deep containing two $3.1 \mathrm{~m}$ deep rooms. The remains (Fig 23) indicate that the rear rooms of the dwellings had a fireplace, situated on the eastern wall, whilst the stairs leading to the first floor were probably located between the front and back rooms (Fig 24). This arrangement directly contrasts to that found in the late $18^{\text {th }}$ century houses, fronting the eastern end of Loom Street (Houses E1-4), where the fireplaces were located on the western wall, with the stairs leading to the first floor found in the rear rooms of the dwellings. Part of a row of four blind-back houses, built between 1807 and 1813, was partially exposed behind the southern frontage of Loom Street. The most extensively investigated of these properties, House E4, formed part of a courtyard development, Blossom Court, which was associated with an outshut that probably functioned as a shared earth-closet privy.

The most common house type excavated within the Loom Street study area was the back-toback dwelling. The earliest examples were constructed between 1807 and 1813 and fronted both George Leigh Street and Jepson's Court (Fig 16). These were accessed via ginnels from both George Leigh Street to the north and Loom Street to the south. ${ }^{36}$ The houses had halfbasements that contained fireplaces on their eastern walls. One property (House C2; Fig 19) measured internally $4.1 \mathrm{~m}$ by $4 \mathrm{~m}$, whilst another (House $\mathrm{C} 1$ ) measured $3.9 \mathrm{~m}$ by $3.9 \mathrm{~m}$. Access into the individual basements was via ladders leading from a trap door, which opened at ground level within each of the dwellings above. There was no evidence for cellar lights for the properties found fronting Jepson's Court, suggesting that if these basements were occupied the living conditions would have been particularly oppressive as they were not lit by natural light or have adequate ventilation.

Another set of back-to-back houses were partially excavated in the southern portion of the development area (Houses F1-3). These were constructed between 1824 and 1831. Like the earlier examples between George Leigh Street and Jepson's Court these back-to-back

Comment [MW25]: Once again, I can't delete the return but think there should not be a para break here. 
dwellings fronted a thorough-fare - Blossom Street - and a smaller courtyard, Blossom Court. The houses were similar in size, measuring $c .3 .9 \mathrm{~m}$ by $3.9 \mathrm{~m}$, and had half-basements, which were probably accessed in the early $19^{\text {th }}$ century via ladders leading from a trap door found at ground floor level. The basements contained fireplaces that had clearly been utilised due to the discovery of an ash pit and cast iron grate. In contrast to those found to the north these half-basements were provisioned with cellar lights allowing the basements to be partially ventilated and lit by natural light.

Between 1836 and 1843 a third set of back-to-back housing was constructed on a previously empty plot of land to the rear of housing fronting the western end of Loom Street and north of Blossom Street. These 12 properties formed part of two separate courts: No.1 and No. 2. No.3 Court, built at the same time, was formed by a row of five blind-backs. (They were first shown on Pigot \& Slater's directory map published in 1843 but had not been on Pigot's directory map of 1836.; Fig 4) Houses G5-7 survived in only a fragmentary state since they had been demolished to make way for new backyards associated with the housing (G1-4; Fig 22) on Loom Street to the north. What survived suggested that they were small properties with no cellars and rooms no more than $3.5 \mathrm{~m}$ square.

\section{LOOM STREET AND THE EVIDENCE FOR IMPROVEMENT INERTIA}

The archaeological evidence from the 46 properties excavated within the Loom Street area demonstrates that poor sanitation and drainage persisted in these properties into the early $20^{\text {th }}$ century. Few of the properties were built with drainage or adequate toilet facilities. In Area A, a pair of brick-built earth closets was built in the yard associated with Houses A1 before $1794{ }^{37}$ These privies may also have been accessed from an alleyway running behind the toilets to the rear of the properties fronting Sheratt Street (Fig 17). To the south in Area B, which fronted the western end of Loom Street, House B4, built between 1794 and 1800, had a rear brick outshut built against its northern elevation which might have acted as an earthcloset (Fig 18). These, though, were the exception. Most housing built in this part of Ancoats shared privy facilities, which could often be some distance from the houses, as appears to have been the case with the back-to-back houses excavated at Hall's Court.

Evidence for primary drainage is also sparse, as was noted during the excavation of the Hall's Court back-to-backs. A late- $18^{\text {th }}$ century brick-lined drain serviced the rear of House B1, although this appeared to be just a soak-away. Likewise a brick-drain-cum-soak-away ran along the rear of the back-to-back houses (C1 and C2 Fig 19) associated with Jepson's Court. No other primary drainage was found within the Loom Street excavations.

The evidence for improvement in sanitary conditions within this area is more extensive, though not universal. Two phases of improvement activity were noted: firstly in the mid-19 century and secondly early in the $20^{\text {th }}$ century. Mid- $19^{\text {th }}$ century improvements were noted in Area B, where a brick outshut to the rear of Houses B1 and B2 was added (Fig 18). They are shown for the first time on the OS 1848 map and may have functioned as an earth-closet. Another pair of brick-built earth-closets was excavated to the rear of House D1, which fronted George Leigh Street. These appear for the first time on Bancks' map of the area in 1831 (Fig 4) and were an addition to the pre-1794 house structure. The base of these privies was roughly $0.3 \mathrm{~m}$ higher than the floor of the basement of D1, and as these new privies abutted that basement seepage from the privies may have been a probable if they were not well maintained. A late- $18^{\text {th }}$-century outshut to the south of House D3, and behind properties fronting Bengal Street to the west, was demolished in mid- $19^{\text {th }}$ century and replaced by a row of three square-plan, brick-built privies, first shown on the 1848 OS map. 
The early- $20^{\text {th }}$-century evidence for extensive remodelling to accommodate new privies was found in two areas. Firstly, in Area E and the site of Blossoms Court the blind-back housing of the court was demolished during the period 1894-1904. ${ }^{38}$ The rear yards for the properties facing Loom Street to the north (Houses E1-E4; Fig 21) were then extended over the site. Each yard was provided with a brick privy serviced by a ceramic drain. Secondly, extensive sanitation improvement took place on the site of the back-to-back housing forming No.1 and No.2 Court north of Blossom Street in Area G. The northern houses of these courts were demolished in the period 1894-1904 and the yards to the terraced housing fronting Loom Street to the north extended into this area (Figs $22 \&$ 23). As at Blossoms Court each yard was provided with a separate brick-built privy with its own ceramic drain.

Evidence for the insertion of foul water drainage, however, is mostly associated with the early $20^{\text {th }}$-century improvements. The only mid- $19^{\text {th }}$-century improvement noted was the insertion of a brick-lined and sandstone-capped drain associated with a row of three squareplan, brick-built privies, behind properties fronting Bengal Street and to the rear of House D3. Two late- $19^{\text {th }}$-century ceramic drains were added to the rear of House B3 and Houses B4 (on the northern side of Loom Street; Fig 18). The rear of the properties fronting Loom Street to the north, Houses E1 to E4 (Fig 21), had ceramic drains inserted in the period 1894-1904 abutting the rear elevations. This was in addition to the sewage drains servicing the new outdoor privies (see above). It is possible that these extra drains may have been associated with a series of brick supports in each of the rear rooms of the houses, which in turn may have supported stone sinks removed during demolition. External foul water drainage was added to the rear of House F2, one of the back-to-backs fronting the southern side of Blossoms Court. This improvement appeared to coincide with the conversion of these properties into through-houses. External drainage was also provided in this period for the houses that abutted the northern side of No.1 and No.2 Court.

These two phases of improvement can be matched with just three pieces of national and local legislation enacted to improve the quality and sanitation of houses in Manchester and other industrial cities. The first wave of improvements in the provision of privies coincided with the Manchester Police Act of $1844 .{ }^{39}$ This might seem somewhat surprising since this Act allowed the new borough to insist on the provision of privies just for new houses, and the evidence from the Loom Street excavations showed that privies after this date were being added to existing properties. The correlation here is therefore not precise, although the Act reflects the general concerns of the period from the Manchester middle class and therefore changes to existing properties need to be viewed within this context. The second housing element of the Act, the banning of the building of back-to-back properties, did have an impact in northern Ancoats: no new back-to-backs appear in this area after the 1840s.

There appears to have been no immediate impact within northern Ancoats from perhaps the best known of the local improvement acts. The Manchester Waterworks and Improvement Act of 1867 aimed at converting or demolishing back-to-back houses within the city. ${ }^{40}$ Yet all of the back-to-back houses within the Loom Street excavations remained unaltered and in use until the early $20^{\text {th }}$ century. Roberts notes that successive Manchester Medical officers were reluctant to reduce the number of dwellings in the inner city for fear of overcrowding in the suburbs. Nor were the city councillors prepared to borrow large sums to convert or demolish housing since this would have increased the rate of local taxation. Whilst the City seems to have been lax in implementing a rigorous inspection regime, various voluntary groups attempted to fill this role, although there are accounts of active resistance to such encouragment in the late $19^{\text {th }}$ century from landlords within Ancoats. ${ }^{41}$ Thus, in the archaeological remains at Loom Street we might be able to see a kind of improvement inertia. 
One of the first indications of change can be seen on the two versions of the Goad insurance map for Manchester surveyed in 1888. The back-to-backs at Hall's Court were amongst the first such housing to be converted to other uses in northern Ancoats and this moment is captured on these maps. In the following two decades all of the back-to-backs in northern Ancoats would be converted or demolished. The context for this was two actions both from 1890: the passing of the Housing of the Working Class Act, and the Manchester Labourers' Dwellings Scheme which was approved by the City in that year.

The first substantial demolition within the Loom Street area was the northern set of six backto-back houses that formed No.1 and No. 2 Courts on the northern side of Blossom Street. In each case the remaining four houses were knocked through into just two houses in each court. The northern-most two houses for No.1 and No.2 Courts were demolished to make way for larger backyards for the houses fronting Loom Street to the north. These changes took place in the period 1894 to 1904 . In the same period the 16 back-to-back houses between George Leigh Street and Jepson's Court were converted into through houses. The northern three blind-backs houses in No.3 Court were demolished entirely, whilst the remaining southern two were converted into a single property. ${ }^{42}$ In the same period the blind-back houses forming Blossoms Court were also demolished, allowing the backyards of the properties fronting Loom Street to be extended to the south. The blind-back housing on the southern side of Jepson's Court was also demolished in the years 1894-1904.

Nevertheless, in the mid- $20^{\text {th }}$ century major change in the housing stock of Ancoats was effected through the progressive demolition of late $18^{\text {th }}$ and early $19^{\text {th }}$ century dwellings of all types: this became the preferred solution to the problems of housing quality and sanitation. This began in the period 1922 to 1932 with the demolition and replacement of housing with commercial or industrial units. In this period five through houses were demolished and replaced by a warehouse on the northern side of Loom Street. By 1951 housing at the corner of George Leigh Street and Bengal Street had been demolished and three properties west of the $20^{\text {th }}$ century warehouse on the northern side of Loom Street had also been removed and the plots left vacant. The main period for demolition, however, was in the following decade. By 1965 only 25 houses were left standing in the Loom Street Study area, mainly along Sherratt Street, and the western ends of Blossom Street and George Leigh Street. ${ }^{43}$ This was typical of the house clearance process across the whole of Ancoats. In the late 1970s only a handful of $18^{\text {th }}$ and $19^{\text {th }}$ century properties was left.

\section{CONCLUSION THE LONG $19^{\mathrm{TH}}$ CENTURY AND HOUSING QUALITY}

The excavation of 57 houses within Ancoats at Hall's Court and Loom Street, complemented by the evidence already published from the excavation of 20 properties at Bradley Street, Holditchs Court and Shilling Court off Jersey Street, demonstrates that archaeology can provide a distinctive and unique view of urban domestic life in $19^{\text {th }}$ - and early- $20^{\text {th }}$-century Ancoats. ${ }^{44}$ The sample size of excavated houses may seem small, these dwellings representing just $13 \%$ of the 600 houses recorded by T R Marr in this part of Ancoats in 1904, yet this material provides a fresh source of data unavailable elsewhere.

One aspect of Ancoats' urban landscape remarked upon by contemporaries, the longevity of the housing stock, has been easily confirmed by this archaeological work. The main phase of house building activity within northern Ancoats was completed by the end of the 1840s. Thereafter, a striking feature of the whole area was not just the excavated sites, but also the continuity of building types and occupation patterns during this period from the 1840 s to 1930s. Despite the construction of new housing in the 1890 s by the city council on the 
northern side of the district fronting Oldham Street, most housing remained intact until demolition in the mid- $20^{\text {th }}$-century demolition. The archaeological evidence can now provide detailed case studies of how little alteration, and by implication investment, took place during the life cycle of most of the houses in Ancoats, forming a 'long $19^{\text {th }}$ century' of social and urban tradition.

The archaeological evidence is less clear in supporting the contemporary accounts of poor quality house construction. ${ }^{45}$ Like Engels before him in 1844, in 1849 the social campaigner Angus Reach noted 'the generic features of the tenements in the older, worse built, and in all respects inferior quarters of Ancoats... They are... a series of little rooms, about ten feet by eight, more or less, generally floored with brick and flagstones - materials which are, however, occasionally half concealed by strips of mats or faded carpeting.' ..."46 The excavated remains at Hall's Court and Loom Street indicate that Engels' and Reach's descriptions were not wholly applicable to this area of Ancoats. For example, within the excavated areas the majority of the worker's houses were constructed of two-course-thick external walls, with one-course wide dividing/party walls, whilst some were surprisingly well constructed such as the late $18^{\text {th }}$ century blind-back houses found at the corner of George Leigh and Sherratt Street, which were constructed of two- and three- course wide brick walls. A number of these properties survived into the mid- $20^{\text {th }}$ century, though some suffered from serious structural problems. This was apparent in the excavated double-depth houses fronting the southern side of Loom Street in Areas E and G, where the internal walls of some of the houses had subsided due to inadequate foundations.

Across the excavated house examples from Hall's Court and Loom Street there was a lack of evidence for amenities both when the properties were first built and by the time they were demolished. Notably absent was running water inside most properties and outside privies throughout the $19^{\text {th }}$ century. Thus, none of the houses within Hall's Court and the Loom Street study area were built with dedicated access to running water, neither internally nor externally, and only some of these properties had that supply installed before they were demolished. Several of the oldest properties were built with dedicated outside privies, but most of the excavated $19^{\text {th }}$ century housing did not, and it was not until the beginning of the $20^{\text {th }}$ century that such facilities were provided. There is extensive evidence to indicate that many of the back-to-backs and blind backs were demolished in the early $20^{\text {th }}$ century before any of the new amenities such as foul water drains, toilets for individual households, and gas supplies were introduced - a phenomenon identified archaeologically in Britain as early as 1994 by Keith Matthews whilst excavating late $19^{\text {th }}$ century and $20^{\text {th }}$ century housing in Chester. ${ }^{47}$ Furthermore, the artefactual evidence from the Hall's Court housing indicates a reoccupation for domestic use after 1900 and until their demolition in 1970, despite their conversion in 1888 .

Why such housing conditions persisted in Ancoats, when other areas of the city had been improved or demolished, is unclear. Each introduction of fresh sanitation and housing quality controls was the start of a process of improvement. The archaeological evidence shows continuity in the housing stock types, which extended to the general lack of improvement both in sanitation and building type between the 1840s and the 1930s, showing that improvements could remain unimplemented or incomplete. This might suggest deliberate neglect by some property owners. Such neglect echoes a comment by Marr in 1904 who noted that to avoid any 'inconvenience if the sanitary authorities take action', that is expense of court action for the landlord if the poor sanitary conditions and overcrowding were discovered, some property owners endeavoured 'to prevent the discovery of its existence'. ${ }^{48}$ 
The archaeological evidence for urbanized, industrial, living presented in this paper through examples of case studies in Ancoats complements the published archaeological studies of manufacturing industry from elsewhere in Britain. The most notable of these has been the study of the Hungate district of York, by the York Archaeological Trust. ${ }^{49}$ This medieval fringe of the city was rebuilt in the late $18^{\text {th }}$ and $19^{\text {th }}$ centuries as an area of densely occupied, poor-quality, housing. Like Ancoats, it was recorded in detail by social commentators, most notable Seebohm Rowntree in 1901. Also like Ancoats, demolition of the housing began in the $1930 \mathrm{~s}$ and was completed in the mid- $20^{\text {th }}$ century. The extensive excavation work here has revealed a complex, and nuanced, story of urban development in the $18^{\text {th }}$ and $19^{\text {th }}$ centuries, challenging through the large collection of objects, the notion of what is poverty, but also highlighting the physical reality of living in one of the poorest areas of the city. ${ }^{50}$ It provides a detailed case-study of the development of industrial suburbs of this period to which Anoats can now be added.

The remains of the cotton spinning and glass manufacturing industries of Ancoats have been the subject of much research and recording since 2000 and in the early $21^{\text {st }}$ century the surviving factories and canal infrastructure dominate the urban landscape of the district. In contrast, the smaller-scale property archaeology discussed here is now only represented by the surviving council housing fronting Oldham Road. Excavation is thus the only way to recover such complex, individual and detailed domestic archaeology during the period 1800 to 1950 and as a consequence provide new material for the story of the rise and fall of Ancoats as one of the earliest industrial suburbs in Britain. 


\section{ACKNOWELDGEMENTS}

I would like to thank the excavation staff of the Centre for Applied Archaeology at the University of Salford for their work on Hall's Court, and members of the former University of Manchester Archaeological Unit for allowing access to the excavation archive for the Loom Street housing. This article has evolved over several years and has benefitted greatly from discussions with Paul Bedford, Director of Clwyd and Powys Archaeological Trust, Lee Gregory, former post-graduate student at the Department of Art History and Archaeology at the University of Manchester, Ian Miller of Oxford Archaeology North, Norman Redhead, former head of the Greater Manchester Archaeology Unit, and Professor Emeritus Marilyn Palmer of Leicester University and President of the AIA.

\section{NOTES AND REFERENCES}

1. Belford P., 'The World of the Workshop: Archaeologies of Urban Industrialisation', in Green A. \& Leech R., (eds.), Cities in the World, 1500-2000. Papers given at the Conference of the Society for Post-Medieval Archaeology April 2002. Society for Post-Medieval Archaeology (2006): Leeds, 133-149; Connelly P., Kendall T., Hunter-Mann K., \& Mainman A, 'The archaeology of modern urban poverty', Current Archaeology 215 (2008), 26-33; Connelly P. A., 2011, 'Flush with the Past: An Insight into Late Ninenteenth-Century Hungate and its Role in providing a Better Understanding of Urban Development', International Journal of Historical Archaeology 15.4 (2011), 607-616; Jeffries N., Owens A., Hicks D., Featherby R. \& Wehner K., 'Rematerialising Metropolitan Histories? People, Places and Things in Modern London', in Horning A. \& Palmer M., (eds.), Crossing Paths or Sharing Tracks? Future directions in the archaeology of post-1550 Britain and Ireland. Boydell \& Brewer Ltd (2009): London, 323-50; Morton D, 'Involving the Public in Glasgow's Industrial archaeology: the M74 Dig', The Archaeologist 74 (2009), 36-7; Nevell M., forthcoming, The Industrial Archaeology of the M74, Glasgow. Society of Antiquaries of Scotland; Symonds J., 'Dirty Old Town? Industrial Archaeology and the Urban Historic Environment', Industrial Archaeology Review 27.1 (2005), 57-65.

2. McNeil R., 'Manchester: Symbol or Model for the World?', in Green A. \& Leech R., (eds), Cities in the World, 1500-2000. Papers given at the Conference of the Society of PostMedieval Archaeology, April 2002. The Society for Post-Medieval Archaeology (2006):Leeds, 151-66. Nevell M., 'Living in the Industrial City: Housing Quality, Land Ownership and the Archaeological Evidence from Industrial Manchester, 1740-1850', International Journal of Historical Archaeology 15.4 (2011), 594-606.

3. Nevell Ref. 2; Connelly Ref. 1; Dwyer E, - The impact of the railways in the East End 1835-2010. Historical archaeology from the London Overground East London line. Museum of London Archaeology, Monograph 52 (2011).

4. Belford P., 'Urban Industrial Landscapes: Problems of Perception and Protection', in Barker D. \& Cranstone D., (eds.), The Archaeology of Industrialisation. Papers given at the Archaeology of Industrialisation Conference, October 1999. Society for Post-Medieval Archaeology (2004): Leeds, 167-9; Nevell Ref. 2. In Manchester the best known commentators are those by Kay J. P., The Moral and Physical Condition of the Labouring Classes in Manchester, (1832), Manchester; Engels F., The Condition of the Working Class in England, London (1845), and Marr T. R., 1904, Housing Conditions in Manchester and Salford: A Report Prepared for the Citizens' Association for the Improvement of the 
Unwholesome Dwellings and Surroundings of the People, with the Aid of the Executive Committee. Sherratt \& Hughes (1904): Manchester.

5. Though all the properties described in this paper were demolished many years ago it is still .possible to follow in some of the footsteps of the old inhabitants of Ancoats. The paved alleyway access to Hall's Court, for instance, still survives, as does most of the road pattern throughout northern Ancoats.

\section{Marr Ref. 4, 55.}

7. Farrer W. \& Brownbill J., (eds.), The Victoria History of the County of Lancaster, Volume 5. Constable \& Co. (1911): London, 220-30; Kidd A., Manchester. Edinburgh University press, third edition (2002), 62-3; Lloyd-Jones R. \& Lewis M., 'Housing Factory Workers', Manchester Region History Review 7 (1993), 33; Phillips C.B \& Smith J. H., A Regional History of England: Lancashire and Cheshire from AD 1540. Longmann (1994): London and New York; the township had just 1646 acres and a population of 70,409 in 1801, 142,026 in 1831 , and 186,000 in 1851.

\section{Nevell Ref. 2.}

9. Roberts J., 'A densely populated and unlovely tract: the residential development of Ancoats', Manchester Region History Review 7 (1993), 15-26.

10. Rees R., Poverty and Public Health 1815-1948. Heinemann (2001): Harlow, 141-50, 1704.

11. Roberts ref. 9, 21.

12. Roberts ref. 2, 23.

13. Roberts ref. $24-5$.

14. Roberts ref. 25; Hartwell C., Pevsner Architectural Guides. Manchester. Penguin Books (2001): London.

15. Rose M. with Falconer K. \& Holder J., Ancoats: The Cradle of Civilisation. English Heritage (2011): Swindon, 64.

16. Little S., 'Ancoats: Protecting the Unprotectable?', Manchester Region History Review 7 (1993), 102-3.

17. Nevell M., 'From Linene Weaver to Cotton manufacturer: Manchester During the $17^{\text {th }}$ and $18^{\text {th }}$ Centuries and the Social archaeology of Industrialisation', in Nevell M., (ed.), From Farmer to Factory owner: Models, Methodology \& Industrialisation. The Archaeology of the Industrial Revolution in North-West England. CBA North West (2003): Loughborough, 2744; Nevell M., Manchester: The Hidden History. History Press (2008): Stroud; Miller I \& Wild C, A \& G Murray and the Cotton Mills of Ancoats. Lancaster Imprints 13, Oxford Archaeology North (2007); Rose et al Ref. 15.

18. Roberts ref. $9,15$.

19. Nevell 2008 ref. 17, 152.

20. Lloyd-Jones \& Lewis Ref. 7, 34. 


\section{Engels Ref. 4.}

22. Kidd A. \& Wyke T., The Challenge of Cholera: Proceedings of the Manchester Special Board of Health 1831-1833. The Record Society of Lancashire and Cheshire volume 145 (2010), ix-xv.

23. Roberts ref. 9, 19.

24. Marr Ref. 4, 54.

25. Marr ref. 4, 56. Roberts Ref. 9, 20.

26. Roberts Ref. 9, 18-9.

27. The two cellar dwellings at Bradley Street, and the twenty dwellings at Holditchs Court and Shilling Court houses were excavated by Oxford Archaeology North in 2005 and 2007; Miller \& Wild Ref. 17, 58-60, and Oxford Archaeology North, Bengal Street Block, Beehive Mills, Ancoats, Manchester: Archaeological Excavation. Oxford Archaeology North (2007), unpublished client report. The Loom Street houses were excavated by the University of Manchester Archaeology Unit in 2007; Gregory R, Blossom Street, Ancoats, Manchester: An Archaeological Desk-Based Assessment. University of Manchester Archaeology Unit (2006), unpublished client report. Gregory R., Loom Street, Ancoats, Manchester. An Archaeological Excavation of Late 18th and 19th Century Workers' Housing. University of Manchester Archaeology Unit (2007), unpublished client report. A watching brief in 2002 recorded the fragmentary remains of $19^{\text {th }}$ century housing between Jersey Street and Henry Street. Lloyd D, Land Bounded by Great Ancoats Street, Redhill Street, Henry Street and Jersey Street, Ancoats, Manchester: An Archaeological Watching Brief. University of Manchester Archaeology Unit (2002), unpublished client report.

28. Green's Plan of Manchester \& Salford, published 1794 and the Manchester Pocket Plan map of 1800 (John Rylands University of Manchester Library map collection). This housing was excavated by the Centre for Applied Archaeology, University of Salford - Cattell S. and Nevell M., The Workers' Housing on vacant land on the corner of Pickford Street and Jersey Street: an archaeological excavation. Unpublished client report, Centre for Applied Archaeology, University of Salford (2011).

29. Charles E. Goad Ltd, fire insurance plans of Manchester, 1888 (Chetham's Library. Manchester).

\section{Cattell \& Nevell Ref. 28.}

31. This work was undertaken by the University of Manchester Archaeological Unit. Gregory 2007 Ref. 27; Nevell 2008, Ref. 17.

32. Another large area of workers' housing was excavated at Angel Meadow in 2009 by Oxford Archaeology North although this remains unpublished.

33. Miller \& Wild Ref. 17, 28.

34. The following maps were consulted in the John Rylands University of Manchester Library map collection: Cole \& Roper's Plan of Manchester \& Salford 1807; Johnsons Plan of the Parish of Manchester 1819; Bancks' Plan of Manchester \& Salford 1831; Adsheads Map of Manchester 1851; Goad's Insurance Plan of Manchester 1888; Ordnance Survey 1:2500 Edition 1894 Lancashire Sheet CIV.7; Ordnance Survey 1:2500 Edition 1908 
Lancashire Sheet CIV.7; Ordnance Survey 1:2500 Edition 1922, Lancashire Sheet CIV.7; Ordnance Survey 1:2500 Revision 1931, Lancashire Sheet CIV.7; Ordnance Survey 1:1250 Edition 1948, Plan 33/8498 NE; Ordnance Survey 1:1250 2nd Revision 1963, Plan SJ 8498 NE; Ordnance Survey 1:1250 Edition 1984, Plan SJ 8498 NE; Ordnance Survey 1:1250 Edition 1999, Plan SJ 8498 NE.

\section{Gregory 2006, Ref. 27.}

36. These properties are recorded for the first time on Pigot's Manchester map of 1813 (John Rylands University of Manchester Library map collection), and in the rate books for the following years.

37. For map references see Ref 34.

38. Ordnance Survey 1:2500 1892-4 map series and Marr's housing quality map published in 1904.

39. Roberts Ref. 9, 22.

40. Roberts Ref. 9, 23.

41. Roberts Ref. 9, 22-4; In other parts of the city new transport facilities were used as an excuse to demolish poor quality housing on the site of Central Station, opened in 1880 and on the site of the Great Northern Railway Warehouse opened in 1896 - Brumhead D., 'Remaking the City: the impact of the railway on late Victorian Manchester', Transactions of the Lancashire and Cheshire Antiquarian Society 100 (2004), 135-158; Nevell 2008 Ref. 17.

42. The period between the OS 6 inch map published 1894 (sheet 105) and the Manchester Housing Quality Map published in 1904

43. Ordnance Survey 1965 map ref.

44. The Bradley Street, Holditchs Court and Shilling Court houses were excavated by Oxford Archaeology North in 2005 and 2007, OAN Ref. 27; Miller \& Wild Ref. 17, 58-60.

45. Kidd Ref. 7; Miller \& Wild Ref. 17; Nevell 2008 Ref. 17; Roberts Ref. 9.

46. Aspin C., (ed.), Angus Bethune Reach: Manchester and the textile Districts in 1849. Reprinted by Helmshore Local History Society, 1972, 6.

47. Matthews K. J., 'Familiarity and contempt: the archaeology of the modern' in Tarlow S. and West S., (eds.), The familiar past? Archaeologies of later historic Britain. Routledge (1999): London \& New York, 155-79.

48. Marr Ref. 24, 56.

49. Connelly, P. A., 'Flush with the Past: An Insight into Late Ninenteenth-Century Hungate and its Role in Provding a Better Understanding of Urban Development', International Journal of Historical Archaeology (2011), 15, 607-616. Rimmer, J., 'People and Their Buildings in the Working-Class Neighbourhood of Hungate, York', International Journal of Historical Archaeology (2011), 15, 617-628.

50. Giles, K. \& Jones, S. R., 'Poverty in Depth: New International Perspectives', International Journal of Historical Archaeology (2011), 15, 544-552; Mayne, A., 'Beond 
Metrics: Reappraising York's Hungate "Slum", International Journal of Historical Archaeology (2011), 15, 553-562.

Dr Michael Nevell is Head of Archaeology at the University of Salford and Director of the Centre for Applied Archaeology in the School of Science and Technology. His is joint editor of Industrial Archaeology Review. Address for correspondence: Centre for Applied Archaeology, College of Science and Technology, University of Salford, Salford M5 4NW. Email: m.d.nevell@salford.ac.uk 